\title{
The New Rutgers University Library
}

$\mathrm{T}$ HE NEW Rutgers University CenTRAL LIBRARY, of red brick trimmed with limestone, was opened last September. Consisting of something over two million cubic feet, the building contains a six-floor stack, which is a large cube 110 by 120 feet. The stacks have been built to take care of a million volumes, with ultimate space for growth to $1,500,000$ volumes.

The lowest floor is entirely below ground level. The next floor has windows on two sides only. The other four floors are above ground. On two sides of this stack block there are two floors of non-stack of steel frame construction. The main entrance is in this second part. Coming from this floor to the stack, the student enters the stack, which is open for free use, at the third floor level. The main entrance is reached through a door next to the circulation department.

\section{Reading Space}

The over-all capacity for readers is twelve hundred. In the stacks there is seating for approximately one-half the readers, distributed as follows: four reading areas in the stack have seating capacity of forty each adjacent to the collections in humanities, science and technology, economics, and a fourth adjacent to the rest of the monograph material in the social sciences. In addition to these reading areas, 280 single study tables are scattered throughout the stack. There are sixty locked carrels, each of which can be used by two people. There are thirty faculty studies, and six sem-

Mr. Cameron is librarian, Rutgers University. inar rooms with a maximum capacity of fifteen each.

\section{Arrangement of Books}

The arrangement of books in the stacks was developed after consultation with faculty committees, and it was agreed that the present arrangement might hold for ten to fifteen years, at the maximum. At that time, a reorganization of free-standing stack will probably be necessary. The plan of location of the books now is as follows: On the main floor adjacent to the circulation desk all the bound periodicals are arranged alphabetically. On that same floor, behind a screen and reached through a control desk, are government documents, except geological publications. On the floor immediately below, all monographs in the social sciences are located, as well as two of the reading areas mentioned above. On the floor above the bound periodicals and documents are the monographs in the humanities, and in science and technology. In each instance, there is a reading room adjacent.

A certain amount of material could not be housed in the three floors mentioned. It is located roughly as follows: In the basement floor is a considerable collection of newspapers. Plans had been made to microfilm these. However, they have come in faster than they could be microfilmed. They are shelved in specially reinforced stacks, which at a later date can be used for regular book storage if the need for the bound volumes of the newspapers disappears. The floor above the humanities, science and technology, houses engineering monographs and periodicals, also military naval sci- 


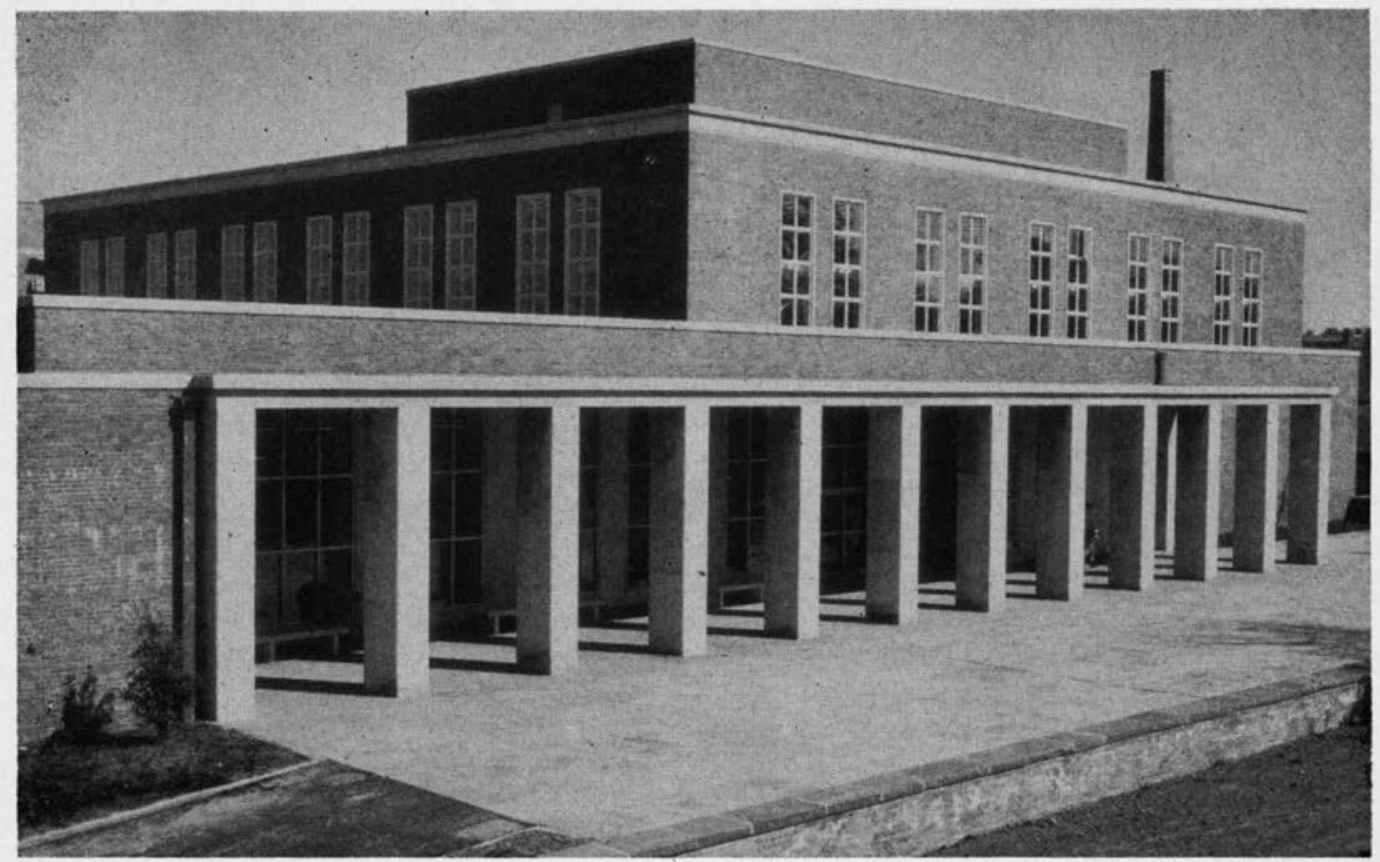

Rutgers University Library

ence and some few special collections. On the sixth, or top, floor we have a collection relating to library service, as well as unsorted matter. At a later date this floor will have three small classrooms made of metal partitions for the use of the Graduate School of Library Service. On this floor also are the thirty faculty studies.

\section{Non-Stack Area}

The non-stack area consists of the main reading room, the periodical reading room, the circulation desk, the catalog, the processing room, the New Jersey room, and the library offices. The capacity of the reference reading room is about two hundred. The capacity of the reserve reading room on the floor below is similar. The current periodical reading room has seating for forty people, and, as an experiment, all periodicals in this area are at present in one alphabet. This arrangement represents a change from a subject arrangement, and has aroused vigorous comment both pro and con among the faculty. At present, more are annoyed than pleased. This collection may later be broken into three alphabets.

The New Jersey Room, located in this area of the building, is part of the special collections. The total seating capacity in this room is about twenty. In the special collections area of two floors, we have a book capacity of about thirty thousand. There is a microfilm area and a projection room with seats for thirtyfive readers.

\section{Equipment}

The lighting throughout is fluorescent. The steel stack, which is free standing, was supplied by Art Metal. This company also furnished the steel locked carrels. The wooden chairs were made to the architect's specifications by Gunlocke, who also supplied the upholstered furniture. The tables, wooden shelving, and book trucks came from the Library Bureau Division of Remington Rand. The card catalog was manufactured by 
the Myrtle Desk Company. The single study tables were made by Scerbo of Brooklyn. All wooden desks, such as the circulation desk, the periodical desk, reserve room desk, government documents desk, and exhibit cases were made by Irving and Casson. The steel office desks and chairs were supplied by Security Steel Company. Three special desks and corner tables were supplied by Knoll Associates. The metal partitions were by Virginia Metal Products.

Problems of Use

Already we have become aware of such an increase in the use of the library that we are discarding all previous statistics. In the stack block we have two passenger-operated elevators which so far have given us a certain amount of trouble. Although the building is built for air conditioning, a test has not yet been run. The air circulation has proved to be somewhat of a problem. It is possible to open the windows, and, as a result, we have students opening windows and throwing the air circulation equipment out of balance. Presumably, such minor inconveniences will disappear with use.

\section{"This Is a House for Reading"}

"My business here is to take care of the house, to answer questions that may be asked, to know the place of books, and to find anything that is wanted." This was the "job description" Hosea Sprague, library assistant at the Boston Athenæum, wrote in telling his brother Isaac of his work at the Athenæum in 1809 . Sprague's letters to his brother are a recent gift to the Athenæum and shed considerable light on the early days of that venerable institution. In reprinting excerpts from the letters in the current issue of Athenaum Items, Walter Muir Whitehill characterizes them as "of particular interest in this sesquicentennial year" of the Athenæum.

"I have been here nearly three months," wrote Sprague September 23, 1809, "for which I receive $7 / 6 \mathrm{pr}$. day which will enable me to pay for my board and cloathes along. I lodge here and board with one Richardson, at the house opposite the Chapel. This is a house for reading-we have about 12,000 volumes of valuable books in the rooms-besides we have 25 files of different newspapers, which lay on the tables, with all new pamphlets, \&c. It [the Athenæum] is divided into 150 shares at 300 dollars each, by which the proprietors expect to make their money. It is managed by Trustees, it has a president and vice president, \&c. All strangers, gentlemen from the southward visit this as one of the curiosities of the town."

Further letters reveal that Sprague, who "always was fond of . . some time to be lazy," worked hard. "I can hardly spare time to go out to get my dinner," he commented. He complained that he was constantly employed as a porter but found time to write in pride of the growing collection of the Library: "We receive books from all parts of the world. Yesterday we received a bundle of books from Constantinople printed in Greek, where it is spoken by the inhabitants. In the winter we had about 15 hundred volumes from France almost the whole of them folios and quartos." 